\title{
Developing a Portfolio Assessment Model for the Teaching and Learning of English in Malaysian L2 Classroom
}

\author{
Charanjit Kaur a/p Swaran Singh ${ }^{1}$, Arshad Abdul Samad ${ }^{2}$, Habsah Hussin ${ }^{2} \&$ Tajularipin Sulaiman ${ }^{2}$ \\ ${ }^{1}$ Faculty of Languages and Communication, Universiti Pendidikan Sultan Idris, Malaysia \\ ${ }^{2}$ Faculty of Educational Studies, University Putra Malaysia, Malaysia \\ Correspondence: Charanjit Kaur a/p Swaran Singh, Faculty of Languages and Communication, Universiti \\ Pendidikan Sultan Idris, Malaysia. E-mail: charanjitt_06@yahoo.com
}

\author{
Received: March 11, 2015 Accepted: May 8, 2015 Online Published: June 29, 2015 \\ doi:10.5539/elt.v8n7p164 URL: http://dx.doi.org/10.5539/elt.v8n7p164
}

\begin{abstract}
Standardized testing is viewed as particularly incompatible to the process of learning due to its summative nature as it measures what students are able to recall and produce. Because of the discrepancy between the process of learning and products of learning, educators today have come to recognize that an alternative form of assessment is required to complement the existing form of assessment. This study intends to determine the techniques ESL teachers use in implementing portfolio as an assessment tool. The techniques ESL teachers employed while implementing the assessment process in the classroom enabled the researchers to propose a model for portfolio assessment. Currently, ESL teachers in Malaysia do not have a specific model or technique to conduct the portfolio assessment process because portfolio is heard of but not widely used. Therefore, this study was carried to scrutinize procedures ESL teachers use as a guide in instructional planning and student evaluation based on their teaching in the L2 classroom. The participants were nine ESL secondary school teachers in Malaysia. Semi-structured interviews, classroom observations and teachers' individual portfolios were utilized to explore the techniques which served as a guideline for ESL teachers employed for the teaching and learning in the classroom. Findings indicate that the portfolio assessment model developed has provided ESL teachers the opportunity to document individual student's growth. Furthermore, the teachers divulged that teaching is sustained when teaching materials, teaching techniques and assessment techniques were upgraded to help students in achieving the learning outcomes. The results of the study have implications for assessment, teaching and learning of English as a second language.
\end{abstract}

Keywords: portfolio, portfolio assessment, ESL instruction and assessment

\section{Introduction}

There are models for portfolio assessment that ESL teachers in Malaysia can use as a guideline. These models are significant in the sense that they offer certain criteria teachers may take into considerations while implementing the portfolio as an assessment tool although at present ESL teachers in Malaysia do not have a specific model or technique to conduct the portfolio assessment process because portfolio is heard of but not widely used (Mohtar, 2010). The techniques ESL teachers used in implementing portfolio as an assessment tool for the teaching and learning in this study enabled the researchers to propose a model for portfolio assessment.

In Malaysia, much emphasis is given to the centralized public summative examination which focuses on students studying only for examination purposes rather than learning for the sake of exploring and gaining knowledge. The standardized examinations reveal that assessment in the Malaysian context is very much examination oriented, resulting in students being passive recipients in the classroom (Chan \& Sidhu, 2010). Providing guidelines on how to implement the portfolio in the Malaysian classroom is an important task that teachers and educators should not ignore because assessment is an integral aspect to sustain teaching and learning.

\subsection{Portfolio Assessment and Portfolio Assessment Model}

Portfolio assessment in the language arts has emerged as an alternative form of assessment recently (Farr \& Tone, 1994; Valencia, 1990; Wolf, 1989). Portfolio assessment is also perceived as an alternative to standardized testing which has been the traditional means of evaluating students (Worthen, Borg, \& White, 1993). Portfolios are considered to be compatible with the process-oriented and meaning construction view of learning (Wiggens, 
1993). One of the most prominent results of portfolio assessment is that it approves the dependence on teacher and student judgment (Farr \& Tone, 1994).

The definition of portfolio varies but there is a general understanding that it is a purposeful collection of student work that provides evidence of growth and achievement over time (Farr \& Tone, 1994). Well-developed portfolios exhibit essential, contextualized learning that needs complex thinking and expressive skills (Herman \& Winters, 1994). Portfolios demand that students continuously collect and reflect on their work. In other words, it places students at the center of the assessment process. Through self-assessment, self-reflection, group discussion, individual presentation, and collaboration with the teacher, portfolio serve as a vehicle for continued growth in the learning process (Routman, 1991).

The concept of portfolio allows for ownership, reflection, and teacher-student interaction (Paulson, Paulson, \& Meyer, 1991). In their study Charanjit and Samad (2013) found that students do not just put the materials into the portfolios instead they have to reflect upon the material, what they have learned from the worksheets and the reasons for compiling the materials into the portfolios. In other words, students acquire ownership of their learning as they are involved in making choices of what goes into their portfolios. When students are aware that they are evaluating their own strengths and weaknesses, it also encourages them to take responsibility for their own learning, and enhance student-teacher communication. As a result, portfolios provide opportunities to improve self-esteem by allowing students to value their own work and themselves as learners (Hansen, 1992).

\subsection{Statement of Problem}

According to the former Malaysia Director of Education, Tan Sri Murad Mohd Noor, "The attitude of being obsessed to too many standardized examinations in the national education system is the factors to not being able to achieve maximum level of creativity and innovation. Too many examinations at primary, secondary and university levels cause students to not having time to develop their talents, ability and potentials in an area of interest" (Utusan Malaysia, 29th September 2005). The rote learning over life-long learning and too examination-oriented system may lead to students not demonstrating real capacities (Mohtar, 2010). One way of assisting weak learners improve their proficiency is to provide assistance to the teachers who are teaching and assessing them (Mohtar, 2010). The teachers' implementation of portfolio as an assessment tool in the classroom enabled the researchers to develop the portfolio assessment model which could serve as assistance to the future teachers who intend to use the assessment in their classroom.

\section{Literature Review}

The current literature on use of portfolio as an assessment tool in the Malaysian education setting is insufficient (Pillay, 2006; Khoo, 2006; Kemboja, 2006; Sidhu, Chan, \& Hazadiah, 2008; R. Mohd \& A. Mohd, 2007; Mohtar, 2010; Chan \& Sidhu, 2010). Missing from the portfolio in second language learning literature is the research that describes the implementation process of portfolio as an assessment tool among Malaysian ESL teachers in the classroom and the learning that takes place. Moreover, surveys of literature published on portfolios reveal that most of the studies on portfolio assessment have been conducted within the first language context, and document perceptions, reflections and experiences of teachers teaching within the context (Udoukpong \& Okon, 2012; Berimani \& Mohammadi, 2013; Czura, 2013; Sliogerine, 2012; Lynch \& Shaw, 2005; Brady, 2001; Klenowski, 2000).

The portfolio and assessment literature shaped the portfolio implementation to a great extent. When implementing portfolio, a number of considerations will assist teachers in using the tool effectively. According to Barrett (2007), novice teachers alone cannot start using the portfolios as the whole process as it is difficult and therefore in their pursuit of portfolio method tended to struggle. Portfolio received great attention as emphasis of instruction on the learning and reflection (Barrett, 2007). The teachers play a versatile role to deliver and communicate the goal of the portfolio development to the students (Barrett, 2007). For teachers to effectively design and implement portfolio assessment, they need a model to provide a framework for their work.

\subsection{Portfolio Assessment Models}

Various existing models outline the essential steps necessary to design and implement portfolio assessment in the classroom Moya and O'Malley (1994). It is very important to have a model for portfolio assessment as it will help ensure the portfolio is a reliable as a valid assessment tool. Fernsten (2005) asserted that clear criteria for evaluation, including what must be put in the portfolio and rubrics for evaluation are vital to successful portfolio assessment. According to Fernsten (2005), portfolio assessment emphasizes the following: clarity of goals, explicit criteria for evaluation, work samples tied to those goals, student involvement in collection of entries, teacher and student involvement in the assessment process, and self-reflections that display students' metacognitive ability, 
that is, their understanding of what functioned for them in the learning process, what did not, and why. These elements further enhance the learning experience and the self-understanding of the student as learner.

\subsubsection{Barnhardt et al. (2003)}

This model of portfolio assessment was proposed by Barnhardt et al. (2003). In their model, there are seven main steps in portfolio assessment:

Step 1: Plan for the assessment purpose

Step 2: Determine portfolio outcomes

Step 3: Match classrooms tasks to outcomes

Step 4: Establish criteria for assessment

Step 5: Determine organization of the portfolio

Step 6: Monitor the portfolio process

Step 7: Evaluating the portfolio process

The above model requires teachers to come up with the assessment purpose and then determine the portfolio outcomes. The steps described in step 1 and 2 are redundant as teachers have to follow the learning outcomes first before they could match it with the assessment purpose. It is crucial for teachers to come up with the types of assessment task or activity based on the learning outcomes to be achieved.

\subsubsection{Moya and O'Malley (1994)}

Moya and O'Malley (1994) developed the portfolio assessment model (PAM) where it consists of six interrelated levels of assessment activities such as the following:

1) Identify the purpose and focus of the portfolio procedure

2) Plan portfolio contents

3) Design portfolio analysis

4) Prepare for instruction

5) Plan verification of procedures

6) Implement the model

The model proposed by Moya and O'Malley (1994) is more feasible as it requires teachers to identify the purpose and focus of the portfolio procedure. Teachers can identify and match the purpose and focus of the portfolio based on the learning outcomes. What is missing from this model is the emphasis on learning outcomes which is important to ensure that the assessment tasks are appropriately constructed or selected. As for the second step which is to plan portfolio contents, the model should consider students' voice in terms of materials compilation for the portfolio. By doing so, teachers allow student autonomy to take place and understand their needs in learning.

\section{Research Design}

The study was a qualitative one as it was an attempt to understand human experience. Yin (2003) defines qualitative case study as an approach to research that facilitates exploration of a phenomenon within its context using a variety of data sources. This ensures that the issue is not explored through one lens, but rather a variety of lenses which allows for multiple facets of the phenomenon to be revealed and understood (Baxter \& Jack, 2008).

According to Yin (2003) a case study design should be considered when: (a) the focus of the study is to answer "how" and "why" questions; (b) you cannot manipulate the behaviour of those involved in the study; (c) you want to cover contextual conditions because you believe they are relevant to the phenomenon under study; or (d) the boundaries are not clear between the phenomenon and context. The case is defined by Miles and Huberman (1994) as, "a phenomenon of some sort occurring in a bounded context. The case is, "in effect, your unit of analysis" (p. 25). For this study, a case study was chosen because the case was the development of portfolio assessment model by the ESL teachers, more specifically the development of the model in the classroom settings. It was in these settings that the portfolio assessment model emerged via the ESL teachers' teaching and learning process. It would have been impossible for the researchers to have a true picture of the development of portfolio assessment model by the ESL teachers without considering the context within which it occurred. 


\subsection{Instrumentation}

\subsubsection{Semi-Structured Interview}

This study utilized semi-structured type of interview. Although guided questions were prepared from the observed lessons and field notes, using a semi-structured interview framework conveyed that a sense of flexibility will be retained. Furthermore, these questions were in sequential but also act as guidelines for the areas that could elicit responses to the research questions. Researchers state that the advantage of having semi-structured interview is that it will assist the researcher to stay alert to the focus of the study and at the same time be open minded to discover spontaneous and new ideas that will emerge during the interview sessions (Kvale, 1996; Gillham, 2000; Radnor, 2001; Silverman, 2005).

\subsubsection{Classroom Observations}

Non-participant observation was conducted when the teachers were teaching. The objective was to obtain information concerning teachers' implementation of portfolio assessment that would enable the researcher to observe the model that would emerged in the study. The researcher managed to observe all the nine teachers teaching during their lessons. There was no intervention by the researcher while the teachers were teaching.

\subsubsection{Sampling and Participant Selection}

The study sought ESL teachers who were familiar with the implementation of portfolio as an assessment tool who have experienced the process of assessment explicitly to chart students' learning in the classroom. Their unique experiences contributed to the understanding of the essence of the phenomenon as it revealed through the portfolio implementation, their experiences in carrying out the portfolio assessment process and the techniques they used in facilitating the portfolio implementation to develop a model of portfolio assessment. Participants were purposefully selected through "snowball" or "chain" sampling (Patton, 1990). This approach "identifies cases of interest from people who know, that cases are information rich, that is, good examples for study, good interview subjects" (Patton, 1990, p. 182). For this study, a snowballing sampling technique was employed to choose the participants (Patton, 1990). This technique was seen most suitable because the researcher cannot determine which teachers have carried out portfolio assessment. The snowballing sampling technique involves asking a participant to refer the researcher to other participants (Merriam, 1998). According to Bogdan and Biklen (1982), Lincoln and Cuba, (1985), Merriam, (1998), the sample in a qualitative study tends to be small and the selection of the participants is purposive. The assumption with purposive sampling is that "the researcher wants to discover, understand, and gain insight and therefore must select a sample from which the most can be “learned' (Merriam, 1998, p. 61).

\section{Research Question:}

What portfolio assessment models would be appropriate in implementing portfolio assessment for the teaching and learning in Malaysian classrooms? To answer this question, data from the teacher's interviews and classroom observations, teacher's individual portfolios were used to examine, analyzed and interpret.

\section{Findings}

\subsection{The Proposed Portfolio Assessment Model and Its Appropriateness}

The idea of observing and interviewing the nine ESL teachers was to construct an appropriate portfolio assessment model applicable in classes with students whose proficiency in English varied from low to high. It was fundamental for the teachers to come up with this portfolio assessment model due to insufficient and suitable reading materials and resources for students which were felt as a great challenge to the ESL teachers. The teachers have to work with inadequate resources to combat the poor performance of their students in the English Language examination paper. English language proficiency among rural students specifically in this study is very low. The decline in English language competency had influenced teachers in this study to help their students to master the language via portfolio assessment. The teachers in this study were certain that they could motivate the students to learn and therefore produce impressive results by integrating portfolio assessment into their learning. In a context where English is learned in an environment which provides very little exposure to the language, the teachers' effort to bring about positive results is very much influenced in their capabilities. In this study, the teachers shared that students hardly used English as it is the second language in terms of importance to them. Although it is compulsory for the students to attend English Language lessons it is not compulsory for them to pass the English Language paper in any examination. The English language is used only when the subject English language is taught in the classroom. The low English proficiency level of the students and indifference toward the language posed challenges to the teachers. Therefore, the teachers introduced portfolio assessment to their students with the hope of assisting weak learners to improve their learning. The portfolio 
assessment model was constructed to guide learners to write compositions, improve mastery of English literature, expand vocabulary acquisition, reinforce grammar skills and create opportunities for learners to speak confidently. The portfolio assessment model derived in this study outlined several stages considered crucial for teachers to apply in their classrooms. The following is the portfolio assessment model which exemplifies the stages involved in its implementation:

1) Specify important skills:

- Listening, speaking, reading and writing skills

- design assessment purpose from learning outcomes

2) Teachers' instructional strategies

-explaining the task

-interesting \& meaningful learning activities

3) Teacher assesses students' work

-record student's score

-students compile work in portfolios

4) Teacher provide feedback on performance

- Students write self-reflection, fill in the self-assessment form \& do peer-assessment

5) Provide opportunities for practice for students

- Enhancement activities for good students

- Remedial activities for weak students

6) Compiling evidence of "best efforts" in a portfolio

7) Evaluate the contents of portfolio using a rubric

All the nine teachers implemented portfolio assessment in a similar manner except for teacher A who felt that there was a need to provide more practice for students after grading their work. This was done after the teacher marked and analyzed her students' grades. The teacher divided the students into two categories mainly into good and weak; she provided remedial activities for weak students and as for the good students, the teacher came up with some enhancement activities. The teacher felt that the extra worksheets were required to confirm how each student fared in understanding topics taught in the classroom. Teacher A shared that portfolio assessment is an on-going assessment, an assessment that allowed her to monitor and assess her students continuously and not just depend on the summative examination solely as shown in the following excerpt:

So this is what we do last year and we found that there are some of the improvement and we found out that students really learn through this portfolio assessment and it also helped the teachers to assess them continuously not only the through the exam. (Teacher A)

Implementation of portfolio as an assessment tool was suitable in her context of teaching because the teacher felt that the students paid more emphasis on studying and preparing for examination and neglecting the crucial aspect of learning and understanding what has been taught in the classroom. With portfolio assessment, the teacher had to introduce other learning activities such as games and puzzles to alter her teaching approach from chalk to talk which she felt could no longer attract the students to concentrate.

The information below exemplifies how the teachers carried out the portfolio assessment into their teaching and learning process in the classroom. This process allowed the researcher to capture main details related to portfolio implementation. Next, the researcher compares the model derived from the ESL teachers' teaching learning in the Malaysian ESL classroom with a model selected from the present literature to show the similarities and differences and how these two models inter-relate with each other. Then, the researcher synthesized the information gathered from the models in terms of importance to the Malaysian learning context. Finally, the researcher also suggests some ways how the present model can be improved and be of help to future teachers who intend to integrate portfolio assessment into their teaching and learning.

The teachers' models in this study identified the four skills (Listening, Speaking, Writing \& Reading). The models reckoned teachers to provide meaningful learning activities for students. The teachers' models introduced classroom activities which required students to interact a lot with their peers and also the teachers. The teachers focused and recorded students' understanding of a topic based on the worksheets given before they could assess 
and grade students' work. The teachers' model in this study emphasized more on recording students' grades after each lesson. The teachers' model did not use any specific rubric although Teacher A in her interview mentioned that she used a rubric to assess student performance. Teacher A did not show the rubric to the researchers but only compiled a list of marks in her portfolio. From the classroom observation made, it was revealed that it was crucial for the teachers to provide feedback on students' performance. There is one appealing and interesting difference in terms of the findings of the study; although Barnhardt's model emphasized providing opportunities for practice to repeat performances/multiple contexts, his model did not indicate to provide practices for both weak and good learners as compared to the teachers' models in which they provide remedial activities for weak learners and enhancement activities for good learners. The advantage of the teachers' models in this study is that it provides opportunity for teachers to identify learners with different learning abilities. Both the models collect evidence of "best efforts" in the portfolio. The teachers' model evaluated contents of the portfolio using proficiency guidelines which were criteria in Barnhardt's model. Although there are some similarities and differences between the teachers' models in this study and proposed model based on the literature, the models are significant in the sense that they offer certain criteria teachers take into consideration while implementing the portfolio as an assessment tool although at present ESL teachers in Malaysia do not have a specific model or technique to conduct the portfolio assessment process because portfolio is heard of but not widely used. These teachers' model ESL teachers used for portfolio assessment in this study will enable future researchers and teachers to understand the steps involved in portfolio assessment.

In Malaysia, much emphasis is given to the centralized public summative examination which focuses on students studying only for examination purposes rather than learning for the sake of exploring and gaining knowledge. The standardized examinations reveal that assessment in the Malaysian context is very much examination oriented that result in students being passive recipients in the classroom. Providing guidelines on how to implement the portfolio in the Malaysian classroom is an important task that teachers and educators should not ignore because assessment is an integral aspect to sustain teaching and learning.

The concern for students' achievement in English received a lot of attention (Tunku Mohani Tunku Mohtar, 2010). One way of helping weak learners improve their language proficiency is to provide assistance to the learners through teachers' instructional practices which are the use of portfolios. The teachers' concern for their students weakness and needs in mastering the English Language make them interact a lot in order to facilitate learning. The teachers agreed that students would learn better with proper guidance. They ensured that the language input they provided were comprehensible enough to make them learn and progress. The teachers divulged that, before instruction, the students were informed about the purpose of doing the portfolio assessment. The purpose of the portfolio assessment was mainly to assist the students to improve their learning. The model described in this study would be of assistance to future teachers who can induce this into their teaching to bring about effective student learning. Current assessment methods do not adequately meet teachers' needs in evaluating performance of their students in targeted grades. Tests do not truly measure the knowledge acquisition by our students. Evidence of this problem is indicated through teacher observations, comparison between student performance on alternative assessment and student performance on traditional tests, and the results of student evaluations.

\subsection{Some Recommendations to the Portfolio Assessment Model}

The researcher felt that the portfolio assessment model emerged in this study based on the teachers' implementation of portfolio assessment can be improved to help both the learners and teachers to bring about effective results in learning. The three suggestions include selecting forms of assessment, reliability and validity of portfolios and parents' involvement as illustrated in Figure 1. 
1. Specify important skills:

- Listening, speaking, reading and writing skills

- design assessment purpose from learning outcomes

2. Teachers' instructional strategies

-explaining the task

-interesting \& meaningful learning activities

3. Teacher assesses students' work

-record student's score

-students compile work in portfolios

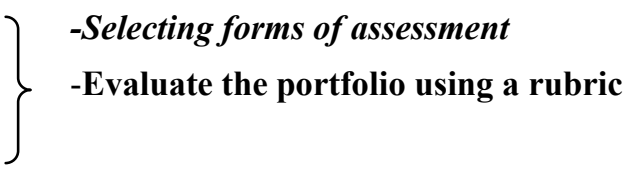

4. Teacher provide feedback on performance

- Students write self-reflection, fill in the self-assessment form \& do peer-assessment

5. Provide opportunities for practice for students

- Enhancement activities for good students

- Remedial activities for weak students

6. Compiling evidence of 'best efforts' in a portfolio

7. Evaluate the portfolio using a rubric

8. Raters/Teachers evaluate the portfolio(new Stage 7)

9. Parents' involvement (new stage 8)

Figure 1. Some recommendations to the Portfolio Assessment Model

\subsection{Selecting Forms of Assessment (for Stage 3)}

First, selecting forms of assessment is imperative to ensure all the students are well guided to develop appropriate learning strategies. The researcher suggests moving the criterion in stage 7 which was to evaluate the content of a portfolio using a rubric. This is because the students need the rubrics at stage 3 to assist them to understand that the tasks or activities created were meant to evaluate student performance at the end of each lesson to ensure that the learning outcomes were understood and achieved by students. The tasks the teachers prepared can range from controlled activities such as substituting words given in a multiple choice format to free writing of composition. However, whatever form of assessment is contrived, the criteria for assessing must be constructed before the tasks are given. The researcher suggests that teachers should include the assessment criteria in stage 3 which can be holistic or analytic depending on the tasks given. A holistic system provides an overall impression of language proficiency while an analytic system provides detailed information of the students' performance. Students should be informed how they are assessed so that they will be able to perform well. For example, for a written composition the rubrics should include information such as "marks will be given for content, language and organization." Students will be motivated to learn as chances of passing are very high.

\subsection{Reliability and Validity of Portfolio (for Stage 7)}

Issues pertaining to reliability and validity have been raised with regard to portfolio assessment. The researcher suggests that all the teachers in this study collaborate to mark portfolios of students from different classes to ensure consistency. Once the respective class teacher has marked and graded students' portfolios, the respective teacher could then submit all the students' portfolios to another teacher for rating purposes. Hence, if two teachers/markers mark and rate the same portfolios the marks awarded would be the consistency in marking can be achieved when the assessment criteria are clearly specified and the raters mark following the same criteria. This aspect was missing from the portfolio assessment model which was considered crucial for portfolio assessment.

As for validity, the teachers provided tasks for students to do after each lesson to check whether or not they have achieved the learning outcomes. If they have not, then the teachers have to find out why students have not achieved them. The teachers can achieve this by entailing further teaching and coaching until the students has finally achieved the learning outcomes. 


\subsection{Parents' Involvement}

Parents' involvement in the portfolio assessment is viewed as another alternative for the students to showcase and share their work compiled to them. This is indirectly would demonstrate individual students' progress in learning. When parents are involved in monitoring the work of their individual child, students will become more responsible because they are now aware that their parents are involved in the assessment process. One of the teachers in this study, teacher A suggested that parental involvement in the portfolio assessment will facilitate learning as the students will have the fear of completing their work which will be then marked, graded and recorded.

\subsection{Portfolio Assessment Model}

The portfolio assessment model was proposed based on the ESL teachers' teaching in the classroom. The portfolio assessment model which is more authentic and student-centered serves as a framework for future ESL teachers who have the intention of using it for their students to bring about effective results in learning. The model draws a way to supplement the traditional approaches to assessment in the form of alternative assessment. Based on teacher's execution of each lesson integrating the portfolio assessment, features as core in conceptualizing portfolio as an assessment emerged and were identified.

Teachers develop the model based on the purpose of using portfolio as an assessment tool through a systematic assessment tool in instructional planning and student evaluation. Teachers planned and organized portfolio assessment so that the students could get a clear picture of what was expected of them when it was implemented. A good portfolio assessment procedure will results in good quality learning. When teachers were able to develop a stringent procedure for portfolio assessment, they could empower students with the required collecting, selecting and reflecting of materials to monitor their own progress in learning. The finding was similar to the models proposed by Moya and O'Malley (1994), Paulson and Paulson (1990), Staehler (1994), Kemp and Toperoff (1998), Gottlieb (1995), Barnhardt (1998), Ferris and Hedgcock (2005).

The models outline the essential steps necessary to design and implement a portfolio assessment in the classroom. It is very important to have a model for portfolio assessment as it will help ensure the portfolio is a reliable and valid assessment tool. Clear criteria for evaluation, including what must be included in the portfolio and rubrics for evaluation are vital to successful portfolio assessment (Fernsten, 2005). Portfolio assessment requiress the following: clarity of goals, explicit criteria for evaluation, work samples tied to those goals, student participation in selection of entries, teacher and student involvement in the assessment process, and self-reflections that demonstrate students' metacognitive ability, that is, their understanding of what worked for them in the learning process, what did not, and why (Fernsten, 2005).

The teachers embrace a critical role in making the portfolio assessment framework accessible to the students because they are the ones who will determine students' needs, strengths and weaknesses and guiding the students towards appropriate learning goals. Collecting evidence is one way teachers can report how their students learn. The teachers were able to tap students' learning when they do the self-assessment. The self-assessment is designed based on the learning objectives that had to be achieved by each and every student in the class. This opportunity supported teachers in terms of understanding the weaknesses of their students and allowed teachers to be resourceful and creative in assisting weak learners.

Teachers revealed that portfolio assessment would be incomplete without students' self-reflection as it informed teachers about their students' strengths and weaknesses in specific areas of learning. Student self-reflection served as a platform for teachers to further delve into the student's present state of competence and their understanding in learning English.

In portfolio assessment, the teachers have to construct the marking system for each task. Marking of students' work is done very frequently so that students are able to chart their own progress. The criteria for marking depend on the type of the task. In short, teachers have to plan, organize, manage, execute lesson, assess, implement the portfolio assessment model and then use these information for problem-solving, deciding students' growth in learning, critical thinking and decision making. Teachers are no longer providing information about students but they are more like information guides. Teachers are the main players in terms of supporting and educating the students about the portfolio assessment so that they can empower students to develop confidence, motivation, independence and sense of ownership in learning.

\section{Conclusion}

The fourth section described the model teachers' use in implementing portfolio as an assessment tool. To be authentic, it is important that an assessment technique demonstrate student growth and achievement in a 
multi-dimensional manner (Moya \& O'Malley, 1994). Therefore, a more viable model is one in which all teachers who teach ESL students contribute to the students' portfolios (Barnhardt, 1998). The model developed in this study based on the teacher's teaching resembled models proposed by Moya and O'Malley (1994), Paulson and Paulson (1990), Staehler (1994), Kemp \& Toperoff (1998), Gottlieb (1995), Barnhardt (1998), Ferris and Hedgcock (2005). The researchers reported that portfolio used for educational assessment must offer more than a showcase for student products; it must be the product of a complete assessment procedure that has been systematically planned, implemented, and evaluated (Ferris \& Hedgcock, 2005). The models are used to reveal the student and instructors, via observation of multiple examples of performances, in different times and contexts, how the students are developing as a learner. It also consists of a variety of performance-based assessments and uses specific criteria and authentic (real life) materials/activities.

\section{References}

Barnhardt, S. et al. (2003). Portfolio assessment in the Foreign Language classroom.

Barrett, H. C. (2007). Researching electronic portfolios and learner engagement: The REFLECT initiative. Journal of Adolescent \& Adult Literacy, 50(6), 436-449.

Baxter, P., \& Jack, S. (2008). Qualitative case study methodology: Study design and implementation for novice researchers. The qualitative report, 13, 544 .

Berimani, S. H., \& Mohammadi, M. (2013). Investigating the effect of portfolio assessment on vocabulary learning of Iranian EFL learners. ELT Voices-india, 3(6), 29-39.

Bogdan, R., \& Biklen, S. (2007). Qualitative research for education (4th ed.). Boston, MA: Allyn \& Bacon.

Brady, L. (2001). Portfolios for assessment and reporting in New South Wales primary schools. Journal of Educational Enquiry, 2(2).

Czura, A. (2013). Implementing portfolio assessment in lower-secondary school. English Language Overseas Perspectives and Enquiries (ELOPE) Journal, 83-94.

Farr, R., \& Tone, B. (1994). Portfolio and performance assessment: Helping students evaluate their progress as readers and writers. Orlando, FL: Harcourt Brace.

Fernsten, L., \& Fernsten, J. (2005). Portfolio assessment and reflection: enhancing learning through effective practice. Reflective practice: Conference Proceedings "Reflections as a Catalyst of Change", 6(2), 303-310.

Ferris, D. R., \& Hedgcock, J. S. (2005). Teaching ESL composition: Purpose, process and practice (2nd ed.). Mahwah, NJ: Erlbaum.

Fook, C. Y., Sidhu, G. K., \& Hazadiah. (2008). Authentic assessment for internationalisation in higher education: A case study. In S. K. Sidhu, M. Sirat, \& N. Azman (Eds.), Globalisation and internationalisation of Higher Education in Malaysia. Pulau Pinang: Penerbit Universiti Sains Malaysia.

Fook, C. Y., Sidhu, G. K., Ariffin, T. R., \& Zamer, N. A. M. (2010). Portfolio assessment: A frontier educational method in ESL classroom. International Conference on Science and Social Research (CSSR 2010), December 5-7, 2010, Kuala Lumpur, Malaysia.

Gillham, B. (2000). The research interview. New York, NY: Continuum.

Gottlieb, M. (1995). Nurturing student learning through portfolios. TESOL Journal, 5(1), 12-14.

Hansen, J. (1992). Literacy portfolio: Helping students to know themselves. Educational Leadership, 49, 66-68.

Herman, J. L., \& Winters, L. (1994). Portfolio research: A slim collection. Educational Leadership, 52(2), 48-55.

Ismail, K. (2009). Portfolios for students' learning in a Malaysian classroom: A Case Study (Unpublished doctoral dissertation). Universiti Kebangsaan Malaysia.

Kemp, J., \& Toperoff, D. (1998). Guidelines for Portfolio Assessment in Teaching English. http://www.anglit.net/ main/portfolio/default.html

Klenowski, V. (2000). Portfolios: Promoting Teaching. Assessment in Education, Police \& Practice, 7(2), 215-236.

Kvale, S. (1996). Interviews: An Introduction to qualitative research interviewing. Thousand Oaks, CA: Sage.

Lincoln, Y. S., \& Guba, E. A. (1985). Naturalistic inquiry. Beverly Hills, CA: Sage.

Lynch, B., \& Shaw, P. (2005). Portfolio, power and ethics. Tesol Quarterly, 39(2), 263-297. 
Merriam, S. H. (1998). Case study research in education: A qualitative approach. San Francisco, CA: Jossey-Bass.

Miles, M. B., \& Huberman, A. M. (1994). Qualitative data analysis (2nd ed.). Thousand Oaks, CA: Sage.

Moya, S., \& O’Malley, M. (1994). A portfolio assessment model for ESL. The Journal of Educational Issues of Language Minority Students, 1-16.

Patton, M. (1990). Qualitative evaluation and research methods (pp. 169-186). Beverly Hills, CA: Sage.

Paulson, L. F., \& Paulson, P. R. (1990). How do portfolios measure-up? A cognitive model for assessing portfolios. Union, Vk An-nual bleeting of the Northwest Evaluation Association.

Pillay, H. D. (1995). Fragments of a vision: A Case Study of the Implementation of English Language Curriculum in Five Malaysia Secondary Schools (Unpublished Ph.D Thesis). East Anglia University.

Radnor, H. (2001). Researching your professional practice. Buckingham: Open University Press.

Routman, R. (1991). Invitations: Changing as teachers and learners. K-12. Portsmouth, NH: Heinemann.

Saad, M. R. M., \& Noor, M. A. M. (2007). Malaysian University Students' Perceptions on the Use of Portfolio as an Assessment tool in an ESL Writing Classroom. Masalah Pendidikan, 30(2), 49-64.

Silverman, D. (2005). Doing qualitative research: A practical handbook (2nd ed.). London: Sage.

Singh, C. K. S., \& Samad, A. A. (2013). The use of portfolio as an assessment tool in the Malaysian L2 classrooms. International Journal of English Language Education, 1(1), 94-108.

Sliogeriene, J. (2012). Students' Reflection Analysis In Portfolios Based Learning. Santalka: Filologija, Edukologij.

Staehler, E. A. (1994). A Guide to Portfolio Assessment in Adult Education Programs. Retrieved from http://elib.uum.edu.my/kip/Record/ED359352

Udoukpong, B. E., \& Okon, C. P. (2012). Perception of formative evaluation practices and students' academic performance in junior secondary certificate examination in social studies. International Journal of Business and Social Science, 3(15), 204-212.

Valencia, S. W. (1990). A Portfolio Approach to Classroom Reading Assessment, The Whys, Whats, and Hows. The Reading Teacher, 1(43), 338-340.

Wiggins, G. (1993). Assessment: Authenticity, context and validity. Phi Delta Kappan, 75(3), 200-214.

Wolf, D. (1989). Portfolio assessment: Sampling student work. Educational Leadership, 46, 35-39.

Yin, R. K. (2003). Case study research: Design and methods (3rd ed.). Newbury Park, CA: Sage.

\section{Copyrights}

Copyright for this article is retained by the author(s), with first publication rights granted to the journal.

This is an open-access article distributed under the terms and conditions of the Creative Commons Attribution license (http://creativecommons.org/licenses/by/3.0/). 